\title{
Anne-Sophie Molinié, Corps ressuscitants et corps ressuscités. Les images de la résurrection des corps en Italie centrale et septentrionale du milieu $d u X V^{\mathrm{e}}$ au début du XVII siècle
}

\section{Michele Mastroianni}

\section{(2) OpenEdition}

\section{Journals}

\section{Edizione digitale}

URL: http://journals.openedition.org/studifrancesi/9494

DOI: 10.4000/studifrancesi.9494

ISSN: 2421-5856

\section{Editore}

Rosenberg \& Sellier

\section{Edizione cartacea}

Data di pubblicazione: 1 décembre 2007

Paginazione: 645

ISSN: 0039-2944

\section{Notizia bibliografica digitale}

Michele Mastroianni, «Anne-Sophie Molinié, Corps ressuscitants et corps ressuscités. Les images de la résurrection des corps en Italie centrale et septentrionale du milieu du xv a au début du xvII siècle», Studi Francesi [Online], 153 (LI | III) | 2007, online dal 30 novembre 2015, consultato il 10 janvier 2021. URL: http://journals.openedition.org/studifrancesi/9494 ; DOI: https://doi.org/10.4000/studifrancesi.9494

Questo documento è stato generato automaticamente il 10 janvier 2021.

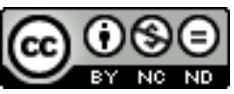

Studi Francesi è distribuita con Licenza Creative Commons Attribuzione - Non commerciale - Non opere derivate 4.0 Internazionale. 


\title{
Anne-Sophie Molinié, Corps ressuscitants et corps ressuscités. Les images de la résurrection des corps en Italie centrale et septentrionale du milieu du XV au début du XVII ${ }^{\mathrm{e}}$ siècle
}

\author{
Michele Mastroianni
}

\section{NOTIZIA}

ANNE-SOPHIE MOLINIÉ, Corps ressuscitants et corps ressuscités. Les images de la résurrection des corps en Italie centrale et septentrionale du milieu $d u x^{e}$ au début $d u x V I I^{e}$ siècle, Paris, Champion, 2007 («Bibliothèque Littéraire de la Renaissance», LXIV), pp. 484.

Si tratta di un lavoro di iconologia e storia dell'arte concernente il tema della resurrezione dei corpi (e quindi del Giudizio universale) nella pittura italiana del Rinascimento. Sebbene concerna un'area culturale diversa da quella francese, segnaliamo qui il volume in quanto il discorso sul ruolo del corpo nell'interpretazione della morte e nell'attesa della redenzione, in relazione con la concezione rinascimentale dell'uomo, come pure il panorama delineato da A.-S. Molinié sulla diffusione dell'iconologia del Giudizio universale, offrono strumenti d'indagine a chi si interessa alla letteratura religiosa di tono escatologico in ambito europeo. Particolarmente utili sono le indicazioni bibliografiche in genere, e in particolare riguardanti quelle opere di spiritualità che sottostanno all'iconologia del Giudizio universale. 